\title{
An Evaluation and Bibliometric Analysis of the New Challenges faced by Corporate Social Responsibility Projects
}

\author{
Maria LOGHIN, Razvan-Catalin DOBREA and Bogdan STOICA \\ The Bucharest University of Economic Studies, Bucharest, Romania \\ Correspondence should be addressed to: Maria LOGHIN; marialoghin1992@gmail.com \\ Received date: 19 Mars 2021; Accepted date:19 July 2021; Published date: 20 December 2021 \\ Academic Editor: Andreea Elena Matic \\ Copyright (C) 2021. Maria LOGHIN, Razvan-Catalin DOBREA and Bogdan STOICA. Distributed under \\ Creative Commons Attribution 4.0 International CC-BY 4.0
}

\begin{abstract}
The reason for including Corporate Social Responsibility (CSR) activities in business processes can be different from cultural and social to economic and financial purposes. Lately, most of the studies have observed the performance of organizations, as a result of including CSR in their structure. Until now, most of the studies advocate that investing in innovation means growing performance. This research emphasizes a new variable with a big impact on organizations performance: quality. Thus, the management teams can pay more attention to this variable in order to improve their organizations performance. This research reviews the work of previous authors and suggests new ideas for further articles on the relation between CSR performance and quality. For this research, 201 publications were analyzed from the WoS database using VOSviewer software.
\end{abstract}

Keywords: CSR projects, quality, CSR performance, impact.

\section{Introduction}

According to the World Business Council for Sustainable Development, CSR represents the organization's efforts for a sustainable development and better quality of life for the society (Cho et al., 2019). The reason for including CSR activities in business structure can be different from cultural and social to economic and financial purposes (Al-Hadi et al., 2019). It is recommended that organizations do not look only at the direct financial performance but also at the indirect

Cite this Article as: Maria LOGHIN, Razvan-Catalin DOBREA and Bogdan STOICA (2021), "An Evaluation and Bibliometric Analysis of the New Challenges faced by Corporate Social Responsibility Projects", Journal of Economics Studies and Research, Vol. 2021 (2021), Article ID 301882,

DOI: $10.5171 / 2021.301882$ 
results, such as improved brand image and reputation, increased quality perceptions of products and services, and customer loyalty (Kirca et al., 2005). This recommendation comes from the fact that CSR activities could be used as a risk management strategy followed by organizations to provide self-insurance against reputational risk (Minor and Morgan, 2011). Excluding CSR from business strategy may lead to negative impacts such as: loss of the organization's reputation, high pressure from media and government, and potential fines (Al-Hadi et al., 2019).

Recently, there have been a lot of debates regarding the effects of corporate social responsibility on organization's performance. There are diverse opinions on whether the cost of implementing CSR activities outweighs the performance implications (Kiessling et al., 2016). According to Kao et al. (2018), the negative relationship between CSR and performance is usually resulting from the implementation of CSR in a short term, while this relation becomes positive in time. For example, environment initiatives, including pollution reduction and process innovation, community support and philanthropic programs require significant upfront costs (Kao et al., 2018). Organizations which are customer oriented and market oriented will have a better chance to succeed in positively integrating CSR activities in business structure (Kiessling et al., 2016). Regarding organizations in the early and decline phase of development's life cycle, CSR activities are likely to be insignificant except for providing an access to the needed capital for survival, growth and sustained financing (Al-Hadi et al., 2019; Newgren and Caroll, 1979). On the other hand, according to Kiessling et al. (2016), most of the customers want the organization to be CSR-centric. In this way, organizations which focus on the current and future value propositions of their customers will distinguish themselves from their competitors and will gain economic benefits (Kiessling et al., 2016). McGuinness et al. (2017) demonstrate that a strong CSR performance is related to gender diversity in management structure, and that disconnecting CSR disclosure by performance may tempt managers to act in their best interests (Garcia-Sanchez et al., 2020). Furthermore, Chen et al. (2019) found that CSR performance is related to CEOs tenure. More exactly, CSR performance is higher in CEOs' early tenure and negative when CEOs have a longer expected tenure. Additionally, Cho et al. (2019) state that CSR performance has a positive impact on the firm's profitability and value. Moreover, corporate social performance and corporate financial performance mutually affect each other: financially successful organizations spend more on CSR activities, while corporate social performance helps organizations become more successful (Orlitzky et al., 2003; Waddock and Graves, 1997). On the other hand, Cheng et al. (2013) advocate that organizations' objective is to obtain profit and that any involvement in CSR activities is rather a way of losing money.

Nowadays, marketplace globalization results in complex and different interactions between multiple stakeholders and organization in the same time (Kiessling et al., 2016). Boards of directors can use CSR as a strategic resource to consolidate stakeholders' relations and organization reputation (Kao et al., 2018). More exactly, paying attention to stakeholders' needs and solving their claims will enhance the organization's reputation and this will have a positive effect on the firm's performance (Kao et al., 2018; Kiessling et al., 2016; Suganthi, 2019; Broadstock et al., 2020). On the other side, avoiding CSR will disappoint these different groups of stakeholders, a fact that will have a negative impact on the organization's performance (Kao et al., 2018).

Recently, the accelerated deterioration of the environment made the researchers come up with innovative ideas about how green practices can contribute to organizational performance (Suganthi, 2019). In addition, consumers are searching for greener products, since their consumption will have a significant impact on the environment (Laureti and Benedetti, 2018). The board of directors must ensure 
that employees are aware of acting environmentally friendly in their daily tasks (Suganthi, 2019). Zotter (2004) suggests that organizations have to focus more on their processes than their products when they want to adopt green practices. In essence, Zotter (2004) states that if the process is carried out with perfection, the products resulted from such a process will be of high quality.

(Suganthi, 2019; Broadstock et al., 2020) advocate that when innovation is introduced into the organization, the firm's performance will be improved. On the other hand, Broadstock et al. (2020) argue that organizations with CSR adoption initially enhance their ability to follow innovation activities, and in time, this will enhance their financial performance.

Although the results are heterogeneous, most of the researchers concluded that CSR has a positive impact on business performance (Kao et al., 2018; Kiessling et al., 2016; Al-Hadi et al., 2019; Suganthi, 2019; Broadstock et al., 2020).

This study adds a significant contribution to the current literature by synthetizing several new ideas and offering new indications for possible future research. More clearly, the relation between quality and CSR performance will be analyzed. This study contributes to the literature by offering a view of the previous studies related to CSR performance. Thus, a bibliometric analysis was performed for creating an analytical view and building robust implications. The authors of this paper hope that this study will be valuable not only for academicians but also for policymakers and professionals. The value of this study lies in the fact that it provides new directions and insights for future research by summarizing the results of the impact of quality on CSR performance.

The rest of the paper is organized as follows: Section 2 elaborates the details of the data collected and the software used for this study; section 3 discusses the results of the bibliometric analysis; and finally, the last section includes the main findings and limitations of the current study as well as future research recommendations.

\section{Methodology}

Data used in this study were extracted from the Web of Science (WoS). The reason for using WoS is that Clarivate Analytics has been rewarded by the Australian Research Council with the Excellence in Research in Austria in 2018 (Zhao et al., 2019). Another reason for using WoS is that it contains all bibliographic information about the authors, citations and journals contained in one database (Ye et al., 2020). This information is helpful in different types of analysis. All indexes from the last five years (2015-2020) were used because this study focuses on the particularities of the projects of social responsibility in the new context of economic development. Since the review was performed at the beginning of 2021, it targeted years (2015-2020). To cover all possible related bibliographic records, the following keywords were identified for data collection: "CSR performance", "CSR projects" and "CSR impact". Based on these keywords, the following combinations were used as a query for searching terms: "CSR impact" OR "corporate social responsibility impact" OR "CSR project*" OR "corporate social responsibility project" OR "CSR performance" OR "corporate social responsibility performance". The authors used ["project*"] in the query including the singular and the plural form of the word. Hence, a preliminary list of 524 bibliographic records was gathered. To ensure that all data collected is accurate, the authors excluded irrelevant records based on the information given by the title and the abstract. Thus, 201 bibliographic records were finally used for analysis.

For this study, co-word, co-citation and bibliographic coupling analysis of bibliometric techniques were used. Coword analysis is about how many times some keywords are used together, while co-citation seeks authors, journals, or documents that are cited together (Zhao et al., 2019). As defined by Kessler in 1963, and quoted by Dwekat et al. (2020), 
bibliographic coupling happens when two papers use a reference as a unity of merging between those two papers.

In this bibliometric review, three types of co-citation analysis, i.e., journal, author and document co-citation were performed. For the bibliometric analysis, VOSviewer software was used.

\section{Results}

\section{Author and co-authorship analysis}

To visualize the corporation network between authors, the VOSviewer software is executed on the collected data set using "Co-authorship" as a type of analysis and "Authors" as a unit of analysis. The minimum number of documents of an author is 3. After running the VOSviewer, Figure 1 was obtained. According to the instruction of (Van Eck et al., 2013), 'links attribute indicates the number of coauthorship links of a specific researcher with other researchers', while total link strength attribute represents the 'total strength of the co-authorship links of a specific researcher with other researchers'. In the current case, the red cluster has the highest link strength (3), which indicates that most of the researches are done independently with significantly less or no long-term, high intensity co-operations between them. According to the analysis (see Table 1), the authors with more than 3 publications are Martinez-Ferrero (4 publications), Karaman Abdullah S. (3 documents), Kilic Merve (3 documents), Uyar Ali (3 documents), Garcia-Sanchez Isabel-Maria (3 documents), and Lopatta Kerstin (3 documents). Among all authors with weak or non-collaborations in their research, Uyar Ali, Kilic Merve and Karaman Abdullah form a strong connection network in their research publications. The co-authored articles of these three authors are recent articles found related to the performance of corporate social responsibility.

lopattakerstin

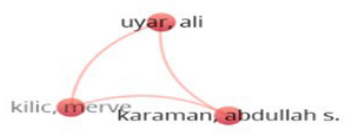

garcia-sanchez isabel-maria

martinez-ferrero, jennifer

\section{Fig 1. Authors' Co-occurrence}

Source: Created by the authors based on WoS database using VOSviewer software 
Table 1: Top authors

\begin{tabular}{|l|l|l|}
\hline Author & Documents & Country \\
\hline Martinez-Ferrero, Jennifer & 4 & Spain \\
\hline Karaman, Abdullah S. & 3 & Kuwait \\
\hline Kilic, Merve & 3 & Turkey \\
\hline Uyar, Ali & 3 & France \\
\hline Garcia-Sanchez, Isabel-Maria & 3 & Spain \\
\hline Lopatta, Kerstin & 3 & Germany \\
\hline
\end{tabular}

Source: Created by the authors based on WoS database.

\section{Affiliation Analysis}

Table 2 presents the organizations' distribution of the documents selected to be analyzed in this bibliometric analysis. It shows that Hong Kong Polytechnic University, University Salamanca and Rmit University contributed the most with 5 publications, followed by Chinese Culture
University with 4 documents. Along with other institutions that can be observed in Table 2, it is found that 5 out of the top 10 institutions are located in China, implying the high focus of studies in the field of CSR projects, CSR performance and CSR impact in this country and in those universities.

Table 2: Top 10 organizations with the largest number of publications

\begin{tabular}{|c|c|c|}
\hline Number of documents & Organization & Country \\
\hline 5 & Hong Kong Polytechnic University & China \\
\hline 5 & University Salamanca & Spain \\
\hline 5 & Rmit University & Australia \\
\hline 4 & Chinese culture University & China \\
\hline 4 & City University Hong Kong & China \\
\hline 4 & Sun Yat-sen University & China \\
\hline 4 & University of electronic Science and Technology & China \\
\hline 3 & American University of the Middle East & Kuwait \\
\hline 3 & University of Groningen & Netherlands \\
\hline 3 & 3 The University of Auckland & New Zealand \\
\hline
\end{tabular}

Source: Created by the authors based on WoS database.

\section{Source of publication}

This section describes the distribution of publications from different journals. Table 3 shows the top 9 journals that have published at least 3 documents in the field of CSR performance, CSR impact, or CSR projects. The most productive journals were found to be "Sustainability" which published $8.96 \%$ documents of the collected sample, followed by "Corporate social responsibility and environmental management" (7.96 \%), "Journal of business ethics" (5.47\%), "Journal of cleaner production" (3.48\%), "Journal of business research" (1.99\%), "Accounting and finance" (1.49\%), "Business and society" (1.49\%), "Corporate governancean international review" (1.49\%), and "Social responsibility journal" (1.49\%). 
Table 3: Top 9 journals (Minimum number of documents of a source: 3 )

\begin{tabular}{l|r|r|}
\hline Journal name & Documents & $\%$ \\
\hline Sustainability & 18 & 8.96 \\
\hline Corporate social responsibility and environmental management & 16 & 7.96 \\
\hline Journal of business ethics & 11 & 5.47 \\
\hline Journal of cleaner production & 7 & 3.48 \\
\hline Journal of business research & 4 & 1.99 \\
\hline Accounting and finance & 3 & 1.49 \\
\hline Business and society & 3 & 1.49 \\
\hline Corporate governance-an international review & 3 & 1.49 \\
\hline Social responsibility Journal & 3 & 1.49 \\
\hline
\end{tabular}

Source: Created by the authors based on WoS database.

\section{Identify the core literature}

Table 4 ranks the most cited articles. "The role of board, gender and foreign ownership in the CSR performance of Chinese listed firms' by McGuinness (2017), which was published in the Journal of corporate finance was the most cited article (102 times). As can be observed, the most cited articles are from Journal of corporate finance, Journal of cleaner production, Journal of business ethics, and Corporate social responsibility and environmental management.

\section{Co-citation analysis}

For finding out if a publication has a high importance in the literature, the number of citations of a specific author and article can be used (Ye et al., 2020).

Figure 2 identifies two main groups of cited documents in the literature. Two documents are strongly related in terms of co-citation links, if the distance between them in the visualization is small (Van Eck et al., 2013). The first cluster is focused on corporate social performance and corporate financial performance link and CSR profit maximization, and it's formed by five very relevant works cited frequently together in this sample (lead by Freeman, Orlitzky, Waddock, Carroll and McWilliams). The green group is made up of three articles about CSR disclosure, usually cited together (Cheng, Dhaliwal and Kim).

\section{Table 4: Rank of the most cited publications}

\begin{tabular}{|c|c|c|c|c|}
\hline Title & Authors & Jounal & \multicolumn{2}{|c|}{ Publication Total Chation } \\
\hline The role of board gender and foregign ounersip in the CSR pertomance of chinese listed fims & Neginess & Joumal of conporate finance & 2017 & 102 \\
\hline The iffuence of CSR practices on organizational pefiomance enidence firom eco-responsible spanish fims & Reverte & Jounal of cleaner production & 2016 & \\
\hline Is corporte social responsibility asciated with tax avidance? & lanis & Joumal of business ethics & 2015 & \\
\hline 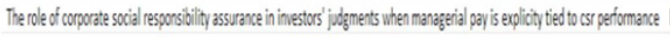 & Brountiburd & Austing a jumal of pratice and theory & 2015 & \\
\hline The impact of corporate social responsibility on risk tacing and firm value & Hajigto & Jounal of business ethics & 2018 & \\
\hline 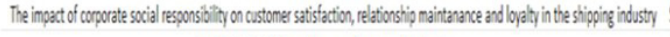 & Shin & Corporate social responsibitity and eniromental management & 2015 & \\
\hline Market orientation and css: perfomance inplications & Kessing & Jounal of business ethics & 2016 & 6 \\
\hline CSR peffomance and the readability of css reports too good to be true? & Warg & Corporate social responsibility and eniromental mangegement & 2018 & \\
\hline The relationship between css and perfomance: eridence in China & $K_{80}$ & Pacifc.basin finance joumal & 2018 & \\
\hline 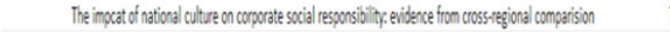 & Thanetsunthor & Asian jounal of business ethics & 2015 & \\
\hline
\end{tabular}

Maria LOGHIN, Razvan-Catalin DOBREA and Bogdan STOICA, Journal of Economics Studies and Research, DOI: $10.5171 / 2021.301882$ 
Source: created by the authors based on WoS database.

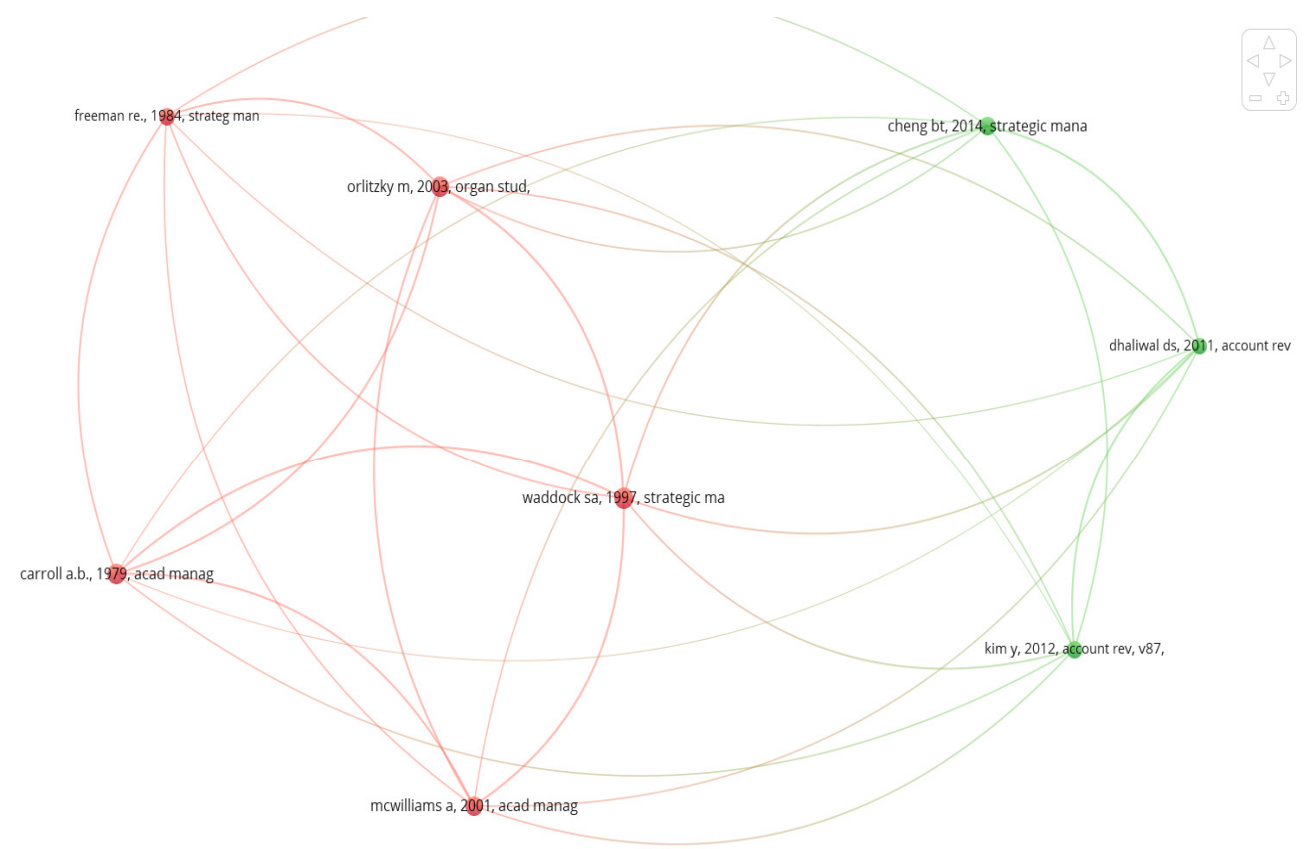

Fig 2. Co-citation (Minimum of 30)

Source: Created by the authors based on WoS database using VOSviewer software

\section{Bibliographic coupling}

For a better understanding of the academic background of the 201 publications selected in this sample, the network of documents referenced was analyzed, revealing that the largest set of connected papers contained 187 documents. Figure 3 presents the documents with the highest link strength of bibliographic coupling (the minimum number of citations of a document is 10).

As can be observed in Figure 3, the three studies with the highest indices of bibliographic coupling are: $>\quad$ Feng, M., Wang, X. \& Kreuze, J. G. (2017). Corporate social responsibility and firm financial performance. American Journal of Business.

$>\quad$ Chen, W. T., Zhou, G. S. \& Zhu, X. K. (2019). CEO tenure and corporate social responsibility performance. Journal of Business Research, 95, 292-302.

Cho, S. J., Chung, C. Y. \& Young, J. (2019). Study on the Relationship between CSR and Financial Performance. Sustainability, 11(2), 343. 


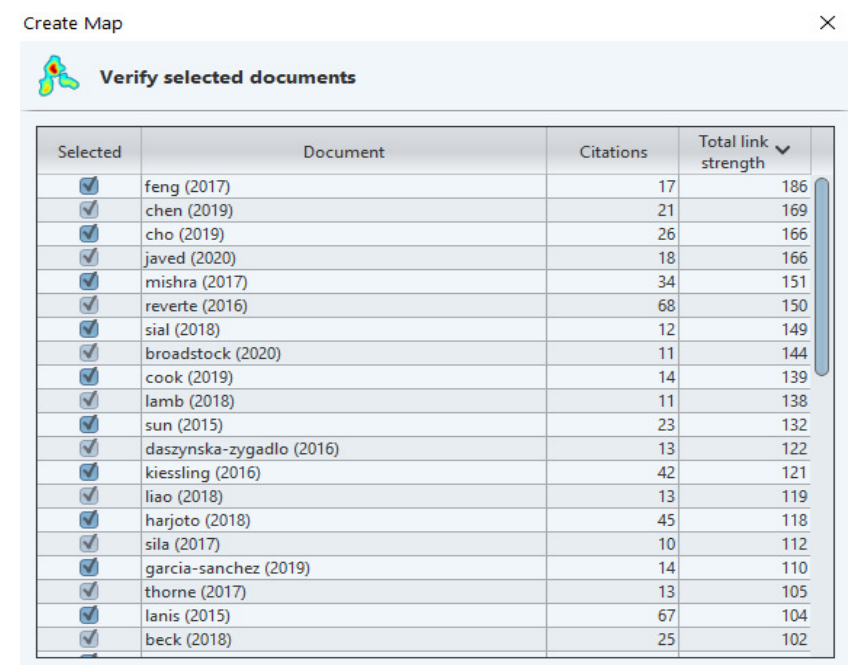

Fig 3. Bibliographic coupling (Minimum of 10)

Source: Created by the authors based on WoS database using VOSviewer software

\section{Most relevant topics in the literature}

Table 5 shows the most frequent keywords that occurred 10 times or more in the field of CSR and CSR performance. 'Corporate social responsibility' and 'financial performance' are the most keywords studied in the area with 111 and 62 occurrences, respectively. Regarding CSR performance, it can be observed that research in the field was focused on financial performance, firm performance and environment performance with keywords' occurrences times of 62, 21 and 16 , respectively. A high frequency for the keyword 'impact' can also be noted, with 35 occurrences. CSR impact can be measured based on the organization's reputation, product quality and the level of innovation, as can be concluded from Table 5, where the keyword 'reputation' appears 16 times, quality 12 times and innovation 11 times. This result is also reflected in the keywords' co-occurrence. Additionally,
Table 6 indicates that studies related to CSR performance are highly related to organizations' reputation and innovation. Concerning the theoretical framework, studies on this field concentrate mainly on the stakeholder theory to explain the association between performance and CSR, respectively, impact and CSR with a frequency of 17 . This result is implying that introducing CSR into an organization's process will have a positive impact on organization's performance. It can also be noticed that the keyword 'China' appears 12 times; this indicates that China is the most influential country in the field, and this is consistent with the previous results illustrated in Table 2.

Regarding keywords' co-occurrence, Table 6 presents the keywords that indicate a strong co-occurrence, which means that they are strong keywords in the field analyzed. 
Table 6: Keyword co-occurrence

\begin{tabular}{l|c|l} 
& Keyword co-occurence & \\
\hline impact & 5 & reputation \\
\hline impact & 6 & performance \\
\hline impact & 3 & quality \\
\hline corporate social responsibility & 16 & performance \\
\hline corporate social responsibility & 22 & impact \\
\hline stakeholder theory & 10 & corporate social responsibility \\
\hline china & 5 & corporate socail responsibility \\
\hline impact & 7 & stakeholder theory \\
\hline impact & 3 & nonfinancial disclosure \\
\hline performance & 5 & innovation \\
\hline performance & 3 & reputation \\
\hline performance & 2 & quality \\
\hline performance & 3 & disclosure \\
\hline innovation & 4 & impact \\
\hline
\end{tabular}

Source: created by the authors based on WoS database.

Table 5: Keyword frequency

\begin{tabular}{|c|c|c|}
\hline Rank & Keyword & Occurrences \\
\hline 1 & corporate social responsibility & 111 \\
\hline 2 & financial performance & 62 \\
\hline 3 & csr & 61 \\
\hline 4 & governance & 46 \\
\hline 5 & corporate social-responsibility & 43 \\
\hline 6 & management & 43 \\
\hline 7 & impact & 35 \\
\hline 8 & performance & 25 \\
\hline 9 & disclosure & 24 \\
\hline 10 & sustainability & 24 \\
\hline 11 & firm & 22 \\
\hline 12 & firm performance & 21 \\
\hline 13 & csr performance & 20 \\
\hline 14 & ownership & 20 \\
\hline 15 & stakeholder theory & 17 \\
\hline 16 & corporate governance & 16 \\
\hline 17 & environmental performance & 16 \\
\hline 18 & reputation & 16 \\
\hline 19 & determinants & 14 \\
\hline 20 & information & 14 \\
\hline 21 & china & 12 \\
\hline 22 & quality & 12 \\
\hline 23 & risk & 12 \\
\hline 24 & corporate social responsibility (csr) & 11 \\
\hline 25 & cost & 11 \\
\hline 26 & innovation & 11 \\
\hline 27 & nonfinancial disclosure & 11 \\
\hline 28 & business & 10 \\
\hline
\end{tabular}

Source: created by the authors based on WoS database.

Maria LOGHIN, Razvan-Catalin DOBREA and Bogdan STOICA, Journal of Economics Studies and Research, DOI: $10.5171 / 2021.301882$ 


\section{Conclusion}

In general, the literature shows that CSR performance is a field where the interest of researchers is growing. The results show that articles by McGuinness et al. (2017), Reverte et al. (2016) and Ianis et al. (2015) have the most important value in the literature, since they are the most cited articles in the field (with more than 66 citations).

Most of the researches are developed in China; however, Spain, Australia, New Zealand, Netherland and Kuwait can also be seen as the main countries interested in studying CSR performance/impact. Considering the most productive authors in this research, it can be seen that they are primarily located in the same countries as the most productive institutions.

The most used keywords in the literature are corporate social responsibility (csr), financial performance/firm performance, management, impact and performance. Furthermore, keyword co-occurrence identifies 'corporate social responsibility and impact', 'corporate social responsibility and performance', 'innovation and performance', and 'stakeholder theory and corporate social responsibility' as the most used keywords.

The literature structure does not identify a robust collaboration between authors. The collaboration between authors is relatively low with three, two, or no collaboration. Uyar Ali, Kilic Merve and Karaman Abdullah formed the strongest connection network in their research publications with three co-occurrences between them, followed by Garcia-Sanchez Isabel-Maria and Martinez-Ferrero with two cooccurrences between them. It is worth noting that Garcia-Sanchez Isabel-Maria and Martinez-Ferrero are both from the same country, Spain, while in the first cluster the collaboration is between authors from different countries.

The co-citation analysis indicates two main groups of cited documents in the literature. The first cluster is focused on corporate social performance and corporate financial performance link and CSR profit maximization, and it's formed by five very relevant works cited frequently together in this sample (lead by Freeman, Orlitzky, Waddock, Carroll and McWilliams). The second group is made up of three articles about CSR disclosure, usually cited together (Cheng, Dhaliwal and Kim). The results of the keywords and co-citations analysis show that CSR performance is studied from the perspective of profit maximization and the relation between the cost of implementing CSR activities and the performance generated. The stakeholder theory is the most popular theory used for explaining the relation between CSR activities and business performance.

One important contribution of this investigation was to identify the key variable that explains the impact of CSR activities on business performance. Most of the studies concluded that innovation activities have a positive impact on business performance (Reverte et al., 2016) and that investing in self-innovation means improving product quality and design for adapting to environmental needs (Kao et al., 2018). Furthermore, in 2009 Gross, quoted by Al-Hadi et al. (2019), it was explained that CSR engagement has a direct impact on organization management. More exactly, organizations which are including CSR activities in their business structure will obtain the highest quality management (Waddock and Graves, 1997). On the other hand, (Reverte et al., 2016) emphasize that creating a better working environment through actions related to employees' health protection, employees' wellbeing and quality of life will lead to a higher degree of innovation. Thus, a further line of research can give more consideration to quality, in a general sense (products/services quality, quality of management and employee quality of life), when researchers want to analyze the impact of CSR on business performance. This statement can be reinforced by the conclusion of (Kiessling et al., 2016) which denotes that customer assessment is based on metrics such as customer-perceived quality and value. 
Finally, this study may have some limitations in the field of research because of the bibliometric techniques used. One of the significant limitations is the possibility of excluding one or more vital articles in the database used.

\section{Acknowledgment}

The authors of this paper would like to thank to the anonymous reviewers and for the technical support given by the editors.

\section{References}

- Al-Hadi, A., Chatterjee, B., Yaftian, A., Taylor, G. and Monzur Hasan, M. (2019), 'Corporate Social Responsibility performance, financial distress and firm life cycle: evidence from Australia,' Accounting \& Finance, 59(2), 961-989.

- Broadstock, DC., Matousek, R., Meyer, M. and Tzeremes, NG. (2020), 'Does corporate Social

responsibility impact firms' innovation capacity? The indirect link between environmental \& social governance implementation and innovation performance,' Journal of Business Research, 119, 99-110.

- Chen, WT., Zhou, GS. and Zhu, XK. (2019), 'CEO tenure and corporate social Responsibility performance,' Journal of Business Research, 95, 292-302.

- Cheng, H., Hong, H. and Shue, K. (2013), 'Do managers do good with other people's money?' (No.w19432), National Bureau of Economic Research. [Online], [Retrieved February 15, 2021],

https://www.nber.org/system/files/w orking papers/w19432/w19432.pdf

- Cho, SJ., Chung, CY. and Young, J. (2019), 'Study on the Relationship between CSR and Financial Performance,' Sustainability, 11(2), 343.

- Dwekat, A., Seguí-Mas, E. and TormoCarbó, G. (2020), 'The effect of the board on corporate social
- responsibility: bibliometric and social network analysis,' Economic ResearchEkonomska Istraživanja, 33(1), 35803603.

- García-Sánchez, IM., Hussain, N., Khan, SA. and Martínez-Ferrero, J. (2020), 'Managerial

- entrenchment, corporate social responsibility, and earnings management,' Corporate Social Responsibility and Environmental Management, 27(4), 1818-1833.

- Kao, EH., Yeh, CC., Wang, LH. and Fung, HG. (2018), 'The relationship between CSR and

- performance: Evidence in China,' Pacific-Basin Finance Journal, 51, 155170.

- Kiessling, T., Isaksson, L. and Yasar, B. (2016), 'Market orientation and CSR: Performance

- Implications,' Journal of Business Ethics, 137(2), 269-284.

- Kirca, AH., Jayachandran, S. and Bearden, WO. (2005), 'Market orientation: A meta-analytic review

- $\quad$ and assessment of its antecedents and impact on performance,' Journal of marketing, 69(2), 24-41.

- Laureti, T. and Benedetti, I. (2018), 'Exploring pro-environmental food purchasing behaviour: An

- empirical analysis of Italian consumers,' Journal of cleaner production, 172, 3367-3378.

- McGuinness, PB., Vieito, JP. and Wang, M. (2017), 'The role of board gender and foreign ownership

- in the CSR performance of Chinese listed firms,' Journal of Corporate Finance, 42, 75-99.

- Minor, D. and Morgan, J. (2011), 'CSR as reputation insurance: Primum non nocere,' California

- $\quad$ Management Review, 53(3), 40-59.

- Newgren, KE. and Carroll, AB. (1979), 'Social forecasting in US corporations-a survey,' Long range planning, 12(4), 59-64.

- Orlitzky, M., Schmidt, FL. and Rynes, SL. (2003), 'Corporate social and financial performance: A metaanalysis,' Organization studies, 24(3), 403-441. 
- Reverte, C., Gomez-Melero, E. and Cegarra-Navarro, JG. (2016), 'The influence of corporate social

- responsibility practices on organizational performance: evidence from Eco-Responsible Spanish firms,' Journal of Cleaner Production, 112, 2870-2884.

- Suganthi, L. (2019) 'Examining the relationship between corporate social responsibility, performance, employees' pro-environmental behavior at work with green practices as mediator,' Journal of cleaner production, 232, 739-750.

- Van Eck, NJ. and Waltman, L. (2013) VOSviewer manual, Leiden: Univeristeit Leiden, 1(1), 1-53.

- Waddock, SA. and Graves, SB. (1997), 'The corporate social performancefinancial performance

- Link,' Strategic management journal, 18(4), 303-319.
- Ye, N., Kueh, TB., Hou, L., Liu, Y. and Yu, H. (2020), 'A bibliometric analysis of corporate social responsibility in sustainable development,' Journal of Cleaner Production, 272, 122679.

- Zhao, X., Zuo, J., Wu, G. and Huang, C. (2019), 'A bibliometric review of green building research

- 2000- 2016,' Architectural Science Review, 62(1), 74-88.

- Zotter, KA. (2004) “End-of-pipe" versus "process-integrated" water conservation solutions: A

- comparison of planning, implementation and operating phases,' Journal of cleaner production, 12(7), 685-695. 